\title{
How many forest and steppe ground and darkling beetles (Coleoptera: Carabidae, Tenebrionidae) are there in West Siberian faunal assemblages?
}

\author{
Сколько лесных и степных жкужелищ и чернотелок \\ (Coleoptera: Carabidae, Tenebrionidae) \\ в сообществах западно-сибирской месостепи?
}

\author{
V.G. Mordkovich \\ B.Г. Моракович
}

Institute of Systematics and Ecology of Animals, Siberian Branch of the Russian Academy of Sciences, Frunze 11, Novosibirsk, 630091, Russia.

Институт систематики и экологии животных СО РАН, ул. Фрунзе 11, Новосибирск 630091, Россия.

KEY WORDS: forest-steppe zone, taiga, steppe, tree stand, grass stand, West Siberian Plain, beetles, ecological spectrum, community, species richness, abundance.

КЛЮЧЕВЫЕ СЛОВА: лесостепь, тайга, степь, древостой, травостой, Западно-Сибирская равнина, жуки, экологический спектр, сообщество, видовое богатство, численность.

ABSTRACT: Zoodiversity of the forest-steppe zone is commonly believed to be resultant of the forest and steppe faunas mixture. According to this notion, the further climate warming is expected to shift the balance between the forest and steppe biotic components towards more aridophilous ones. Many years of terrestrial beetles investigation revealed that their foreststeppe assemblages are dominated by species with polyzonal areas, but having maximal density populations in the forest-steppe zone. Proportion of species with mostly forest and steppe metapopulations does not exceed summarily $30 \%$. The forest-steppe terrestrial beetle assemblages displayed specific ecological group structure dominated by species preferring meadow habitats. Analysis of beetle faunal assemblages' similarity in respect to ecological group dominance structure revealed four series of phylogenesis in the forest-steppe. Each series begins from the transformation of different archetype coenoses, apparently inherited from the periglacial savanna of the last Glacial period, namely peatlands, park forests, halocoenoses and dry meadows. In course of succession all these coenoses are transformed into a single reference one, i.e. meadow coenosis. Beetle faunal assemblages in the forest-steppe are characterized by the most original and dynamically stable composition and structure, occupying more than $70 \%$ of the zonal area with a wide range of habitats. Therefore the meadow coenoses, rather than the fragmentary quasi-steppes and forest-like insular tree stands, represent the indigenous element of the latitudal zone between taiga and steppe. It makes more sense to refer to the corresponding original biome as a meadow, rather than steppe, one.
РЕЗЮМЕ: Зооразнообразие лесостепной зоны обычно считается смесью лесной и степной биот. Согласно этой версии ожидается, в свете грядущего потепления, смещение баланса лесных и степных элементов биоты в пользу более аридных. По итогам многолетних исследований напочвенных жуков выяснилось, что среди обитателей лесостепи преобладают виды с полизональными ареалами, но имеющие популяции с максимальной плотностью в зоне лесостепи. Доля видов с преимущественно лесными и степными метапопуляциями не превышает в лесостепи, суммарно, $30 \%$. Лесостепные сообщества напочвенных жуков отличаются специфической структурой доминирования в спектре экогрупп видов, предпочитающих количественно луговые местообитания. Анализ степени различия сообществ по структуре доминирования экогрупп выявил наличие четырех серий филогенеза в лесостепи. Каждая из них начинается с преобразования разных ценозов-архетипов, унаследованных, видимо, от перигляциальной саванны предшествовавшего ледниковья - торфяных болот, лесопарков, галоценозов и сухих лугов. Все они в ходе сукцессий превращаются центростремительно в единый эталон - луговой ценоз. Луговые сообщества в лесостепи отличаются наиболее оригинальным и устойчивым в динамике составом и структурой, занимают более $70 \%$ площади зоны в широком диапазоне местообитаний. Поэтому именно они, а не фрагментарные квазистепи и лесоподобные колки представляют коренной элемент широтной зоны между тайгой и степью. Соответствующей ей оригинальный биом логичнее именовать луговым, а не лесостепью. 


\section{Introduction}

Landscape ecology of pedobionts has always attracted significant attention of soil zoologists, such as M.S. Ghilarov [1965] and his immediate followers, including B.R. Striganova. The book about pedobiont assemblages and their structure in the latitudal zones of the West Siberian Plain is the most recent major generalization in the field [Striganova, Poryadina, 2005].

In the system of those latitudal zones of particular interest is the forest-steppe zone as it is generally characterized as a marginal mosaic complex of biota at the interface of forest and steppe. The latitudes occupied by the forest-steppe display some extraordinary features in the gradient of environmental conditions from the Equator to the Northern Pole: the broadest environmental conditions range, the balance between evaporation and precipitation, the balance between soil humification and mineralization and very high natural soil fertility, etc. Thanks to all these the forest-steppe may be regarded as a zone of environmental comfort for biota. As a result, species richness along the latitudal gradient reaches its maximum in the forest-steppe. The total biodiversity of arthropods, comprising $90 \%$ of the total fauna biodiversity, amounts to 4,000 species, that is 1.5-2.0 times higher than in the neighbouring forest and steppe zones [Mordkovich et al., 2002].

What is the mechanism causing such a high rate of species richness? The most common concept tends to attribute the latter to the result of a mere summation in the forest-steppe zone of all the species expanding from the north and from the south. Areal analysis seems to confirm this view as no less than $80 \%$ of the foreststeppe biota species, and primarily insects, enjoy polyzonal areas, embracing forest-steppe and forest zones or forest-steppe and steppe zones, or even all three ones. The major issue here is that there are few reasons to consider such species as truly autochtonous foreststeppe ones, intruding to the north and south, and vice versa.

The occurrence of endemic species can serve as an objective criterion for fauna's specificity. There are endemic species in the forest-steppe zone. Analyzing the ground beetles and other insects' faunas in the East European forest-steppe, K.V. Arnoldi [1965] observed dozens of endemic species. According to Siberian entomologists, the degree of endemism for the West Siberian forest-steppe fauna ranges from $1-2$ to $10-15 \%$ for various taxa [Mordkovich et al., 2002]. Nonetheless, arealogical argumentation is not sufficient to infer the indigenous character of the forest-steppe entomological assemblage.

Alongside with the size and contour of the area of crucial importance is the structure of its so called "environmental lace". The term refers to the number and structure of habitats, occupied by certain biological species. In such case species quantitative characteristics and metapopulation architectonics are taken into account [Khanski, 2010].
Ecological criteria enable to answer the question to what degree the composition and structure of insect faunal assemblages of the forest steppe tree and grass stands resembles the reference forest and steppe assemblages. The issue becomes increasingly actual in respect to the global warming, which is often identified with aridisation. In fact the global warming is quite a controversial phenomenon, and in different regions of the world may result either in aridisation or humidification of the environment. Judging by the meteorological data of the recent decades, in the forest-steppe zone of the West Siberian Plain the global warming apparently results in the drastic intensification of annual and seasonal climatic fluctuations [Beresneva, 2006], the latter being quite pronounced even without any warming.

Under such environmental conditions the assembling of insect species into the forest-steppe communities, presumably, should be directed against the organisms with narrow specialization to hyper-humid or super-arid conditions, favouring the species that are tolerant to a broad environmental range. To test this hypothesis we analyzed the taxonomical composition and ecological structure of a) predator ground beetles assemblages, that are abundant and diverse in the forest, forest-steppe and steppe zones, and b) sapro-and phytophagous darkling beetles as most of them, excepting forest and water-dwelling species, are considered to be indicative of aridisation.

\section{Materials and methods}

The study region. The study was carried out in the Plains in the south of West Siberia, Russia (Baraba and Kulunda) and in Central Kazakhstan (Atbasar, Tengiz and Balkhash Plains, Kazakhstan) in the geographical region within $65-44^{\circ} \mathrm{N}$ and $70-80^{\circ} \mathrm{E}$, embracing 3 taiga subzones (the northern, middle and southern ones), 3 forest-steppe subzones (northern, typical and southern ones) and 3 steppe subzones (arid-chernozemic, kastanozemic dry and deserted ones), as well as in the northern subzone of the temperate desert (Cis- and Trans-Balkhash areas). A typical catena with representative ecosystems (eluvial, EL, transit, TR, and accumulative, AC) were chosen. Typical zonal biogeocoenoses that had never been ploughed, regularly hayed, overgrazed or otherwise subjected to anthropogenic land use impact were chosen as reference ecosystems.

Beetle sampling. Ground beetles (Coleoptera: Carabidae) and darkling beetles (Coleoptera: Tenebrionidae) were samples using pitfall traps of $12 \mathrm{~cm}$ diameter. Ten traps were placed at each site. Trapping was conducted monthly since May till August during consecutive 2-3 years at each study site, i.e. on the chosen catena in each latitudal zone and subzones. Traps were operated for $5 \times 24 \mathrm{~h}$ at each study site, with the captured individuals removed and later processed in the laboratory and separated to species. The data used for further analyses represent the sum of individuals 
over 4 seasonal countings in each biotope for 100 trapdays (10 traps $* 20$ days).

The study yielded more than 200 ground beetle species and 17 darkling beetle species. Therefore the list of genera and species is not comprehensive of the biodiversity of ground beetles and darkling beetles faunas of the studied region, but includes only those faunal components, that played the major role in shaping beetle assemblages.

To compare beetle assemblages we used the following index of difference:

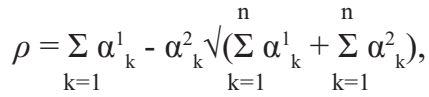

where $\alpha^{1}$ and $\alpha^{2}$ are numbers of a certain species $(\mathrm{k})$ in the $1^{\text {st }}$ and $2^{\text {nd }}$ communities, respectively, while $\Sigma \alpha^{1}{ }_{k}$ and $\Sigma \alpha^{2}$ are the sums of species numbers from the 1 to the $n$ species of the $1^{\text {st }}$ and $2^{\text {nd }}$ communities, respectively.

To compare faunal assemblages we also used the biological diversity index, calculated as $\mathrm{M}=\mathrm{a} / \mathrm{vb}$, where a stands for the total number of species, and $b$ is the total number of insects in the community [Magurran, 1992].

\section{Results}

In the forest-steppe zone and chernozemic subzone of the steppe zone the ground beetle species richness in the studied catena biotopes $(\mathrm{EL}+\mathrm{TR}+\mathrm{AC})$ reached 90-92 species. In the dry kastanozem steppes the ground beetle species richness decreased almost 2-fold (58 species), and still farther to the south decreased to just 28 species in the deserted steppe.

Latitudally, the number of the ground beetle genera decreased less seriously, from 23-24 genera to 16-19 per catena.

The darkling beetle fauna displayed quite the opposite pattern of species richness changes from north to south, as the number of their species increased from just 5 species in the grass stands of the forest-steppe to 8-9 species in the chernozemic and kastanozem steppe zones and farther to the south up to 12 species in the deserted steppe subzone. The number of ground beetle genera increased from 4 in the forest-steppe to 8 genera in the steppe and 10 in the deserted steppe subzones.

The similarity index between the ground beetle faunas of the insular tree stands of the West-Siberian forest-steppe and zonal forests of the West Siberia and East Europe was not high. For instance, the communality of ground beetle faunal composition between the park forest of the forest-steppe and zonal southern taiga in the West Siberia did not exceed 19\%. The ground beetle faunas similarity between the hydromorphic forest-steppe insular tree stands and zonal southern or middle taiga was not higher than $13 \%$, whereas the ground beetle faunas similarity between the semihydromorphic insular tree stands of the northern for- est-steppe and the riverside forest in the Siberian southern taiga was $25 \%$. Species composition of the insular tree stands of the West-Siberian forest-steppe and oak stands of the East-European forest-steppe was estimated to be slightly higher (25-30\%), but only due to nonspecialized hydrophilous species: Pterostichus nigrita (Paykull, 1790), Pt. vernalis (Panzer, 1795), Platynus assimilis (Paykull, 1790), Elaphrus cupreus (Duftschmid, 1812).

The taxonomical similarity of the ground beetle assemblages between the forest-steppe meadows and different arid and dry steppes did not exceed 30 and $20 \%$, respectively. We did not find species that were common for the faunas of the forest-steppe and deserted steppe.

The similarity of darkling beetles faunas between the forest-steppe and steppe zones was higher than that of the ground beetles, but likewise did not exceed $50 \%$. The highest values of the Jaccard index were calculated between the local faunas of the meadow steppe and stepped meadow in the forest-steppe zone, on one hand, and between solonetz steppe meadows of transit ecosystems in the steppe zone, on the other hand, most likely due to the increased moisture because of the lateral soil water flow.

In general the comparison of ground beetle and darkling beetle species richness did not provide reasons to consider the forest-steppe fauna a continuation or at least a derivative of the steppe fauna, showing its independent character.

\section{Ecological characteristics of species}

Taxocoenes of zoophagous and mixophagous ground beetles and saprophytophagous darkling beetles occupy different trophical niches, however, their biotopical preferences coincide. Because of this, to compare these taxocoenes, we chose ecological groups, determined a priori according to the species population distributions in relation to a single standardized zonal catena matrix of habitats. Ecological groups are composed on the basis of selective attitude of different insect species in the geographic and ecographic space of limiting environmental factors, i.e. temperature, moisture, substrate texture, vegetation cover (Table 1). The general principles of ecological groups typology were explained in detail earlier [Mordkovich, Lubechanskii, 2010; Mordkovich, 2011]. Below we provide the revised sets of ecological groups that are characteristic for the West Siberia and Central Kazakhstan ecosystems, as well as ground beetle and darkling beetle species comprising each group.

Forest cryohygrophiles (FCH). These beetles had maximal abundance in the mired tree stands of the TR and AC taiga catena ecosystems, but were also common, albeit less abundant, in the grass wetlands of the forest-steppe. FCH are represented mostly by the ground beetles: Notiophilus reitteri (Spaeth, 1900), Leistus terminatus (Hellwig, 1793), Patrobus septentrionis (Dejean, 1828), Platynus mannerheimi (Dejean, 1828), 
Table 1. Hierarchal classification of ground beetle topoecotypes of the West Siberian and Central Kazakhstan plains in relation to habitat insolation, total moisture and plant ecobiomorphs, dominating in coenoses.

\begin{tabular}{|c|c|c|}
\hline $\begin{array}{l}\text { Insolation intensity and } \\
\text { regime preferred }\end{array}$ & $\begin{array}{l}\text { Environment moisture rate and } \\
\text { regime preferred }\end{array}$ & $\begin{array}{l}\text { Phytocoenoses with dominating plant } \\
\text { ecobiomorphs preferred }\end{array}$ \\
\hline \multirow{2}{*}{ Eucryophiles } & Hygrophiles & $\begin{array}{l}\text { Shrubs } \\
\text { Grass } \\
\text { Mosses and lichens }\end{array}$ \\
\hline & Mesophiles & $\begin{array}{c}\text { Shrubs } \\
\text { Grass } \\
\text { Mosses }\end{array}$ \\
\hline \multirow{2}{*}{ Semicryophiles } & Hygrophiles & Grass \\
\hline & Mesophiles & Forest \\
\hline \multirow[t]{2}{*}{ Ardophiles } & Hygrophiles & $\begin{array}{l}\text { Tugai-forest } \\
\text { Tugai-grass } \\
\text { Euphemroides }\end{array}$ \\
\hline & Xerophiles & $\begin{array}{c}\text { Grass } \\
\text { Shrubs }\end{array}$ \\
\hline \multirow{3}{*}{ Thermophiles } & Xerophiles & \multirow{3}{*}{$\begin{array}{l}\text { Shrubs } \\
\text { Grass }\end{array}$} \\
\hline & Mesophiles & \\
\hline & Hygrophiles & \\
\hline Psychrophiles & Hygrophiles & $\begin{array}{l}\text { Grass } \\
\text { Forest }\end{array}$ \\
\hline
\end{tabular}

Sericoda quadripunctata (De Geer, 1774), Curtonotus gebleri (Dejean, 1831), Bembidion gilvipes (Sturm, 1825), Badister peltatus (Panzer, 1796), Trachypachis zetterstedti (Gyllenhal, 1810).

Grass cryohygrophiles (GCH). These insects showed maximal abundance in the grass AC wetland ecosystems of taiga catenas and are represented mostly by Acupalpus dorsalis (Fabricius, 1787), Agonum dolens (Sahlberg, 1827), A. impressum (Panzer, 1796), A. livens (Gyllenhal, 1810), A. longiventre (Mannerheim, 1825), A. piceum (Linnaeus, 1758), Amara erratica (Duftschmid, 1812), A. interstitialis (Dejean, 1828), Blethisa multipunctata (Linnaeus, 1758), Chlaenius tristis (Schaller, 1783), Nebria livida (Linnaeus, 1758), Pelophila borealis (Paykull, 1790), Pterostichus nig- rita (Paykull, 1790), P. gracilis (Dejean, 1828) and others.

Grass cryomesophiles (GCM). This group showed maximal abundance in the standing grass of the taiga TR ecosystems, and its major components were the ground beetles: Amara aenea (De Geer, 1774), A. bifrons (Gyllenhal, 1810), A. consularis (Duftschmid, 1812), A. praetermissa (Sahlberg, 1827), A. quenseli (Schonherr, 1806), Badister bullatus (Schrank, 1798), Cicindela silvatica (Linnaeus, 1758), Clivina fossor (Linnaeus, 1758), Curtonotus alpinus (Paykull, 1790), Harpalus solitaris (Duftschmid, 1812).

Forest psychrohygrophiles (FPH). This group displayed maximal abundance in the mired tree stands of the forest-steppe AC ecosystems, being represented 
mostly by the ground beetles: Pterostichus diligens (Sturm, 1824), Platynus assimile (Paykull, 1790), Agonum fuliginosum (Panzer, 1809), A. krynickii (Sperk, 1835), A. thorey (Dejean, 1828), Badister bipustulatus (Fabricius, 1792), B. laecertosus (Sturm, 1815), Carabus granulatus (Linnaeus, 1758), C. violaceus (Linnaeus, 1758), Oodes helopioides (Fabricius, 1792).

Forest psychromesophiles (FPM). These beetles reached maximal abundance in the tree stands of the forest-steppe EL and TR ecosystems, including mostly the following ground beetles: Agonum lugens (Duftschmid, 1812), A. brunnea (Gyllenhal, 1810), A. communis (Panzer, 1797), Amara majuscula (Chaudoir, 1850), Carabus convexus (Fabricius, 1775), C. glabratus (Paykull, 1790), C. marginalis (Fabricius, 1794), C. sibiricus (Fischer von Waldheim, 1820), Calathus melanocepalus (Linnaeus, 1758), Synuchus nivalis (Panzer, 1797), Notiophilus palustris (Duftschmid, 1812), N. germinyi (Fauvel, 1863), Harpalus latus (Linnaeus, 1758), H. cisteloides (Motschulsky, 1844), $H$. pumilus (Sturm, 1818), Licinus depressus (Paykull, 1790), Panagaeus cruxmajor (Linnaeus, 1758), Poecilus versicolor (Sturm, 1824), Pterostichus melanarius (Illiger, 1798), P. oblongopunctatus (Fabricius, 1787), Rhopalostyla virgata (Motschulsky, 1844).

Grass psychrohygrophiles (GPH). This group was found to reach maximal abundance in the forest-steppe grass wetlands and was comprised primarily of the ground beetles: Agonum versutum (Sturm, 1824), A. viduum (Panzer, 1797), Amara famelica (Zimmermann, 1831), A. nitida (Sturm, 1825), Bembidion assimile (Gyllenhal, 1810), B. biguttatum (Fabricius, 1779), B. guttula (Fabricius, 1792), Carabus clathratus (Linnaeus, 1761), C. maeander (Fischer von Waldheim, 1822), Chlaenius nigricornis (Fabricius, 1787), Ch. costulatus (Motschulsky, 1859), Dametrias monostigma (Samouelle, 1819), Dromius ruficollis (Motschulsky, 1844), Dyschirius strumosus (Dejean, 1825), Elaphrus cupreus (Duftschmidt, 1812), E. sibiricus (Motschulsky, 1844), Loricera pilicornis (Fabricius, 1775), Patrobus assimilis (Chaudoir, 1844), Pterostichus aterrimus (Herbst, 1784), P. cursor (Dejean, 1828), P. minor (Gyllenhal, 1827), P. vernalis (Panzer, 1795), Trechus rivularis (Gyllenhal, 1810), Trichocellus cognatus (Gyllenhal, 1827).

Grass psychromesophiles (GPM). The group had maximal abundance in the forest-steppe TR grass stands and was represented by the ground beetles: Amara equestris (Duftschmid, 1812: 109), A. similata (Gyllenhal, 1810), A. ovata (Fabricius, 1792), A. infima (Duftschmid, 1812), A. plebeja (Gyllenhal, 1810), Bembidion quadrimaculatum (Linnaeus, 1761), Cicindela campestris (Linnaeus, 1758), C. chiloleuca (Fischer von Waldheim, 1820), Curtonotus torridus (Panzer, 1796), C. aulicus (Panzer, 1796), Calathus erratus (C.R. Sahlberg, 1827), Callistus lunatus (Fabricius, 1775), Carabus tuberculosus (Dejean, 1829), Harpalus affinis (Schrank, 1781), H. kirgisicus Motschulsky, 1844, H. subcylindricus (Dejean, 1829), Notiophilus aquaticus
(Linnaeus, 1758), Lebia cruxmior (Linnaeus, 1758); and darkling beetles such as: Crypticus quisquilius (Linnaeus, 1760), Opatrium riparium (Scriba, 1865).

Grass psychrobalancephiles (GPB). This group reached maximal abundance in the EL grass stands of the forest-steppe and chernozemic steppe catenas and was represented by the ground beetles Agonum muelleri (Herbst, 1784), Poecilus fortipes (Chaudoir, 1850), P. lepidus (Leske, 1785), P. sericeus (Fischer von Waldheim, 1824), Harpalus smaragdinus (Duftschmid, 1812), H. calceatus (Duftschmid, 1812), H. froelichi (Sturm, 1818), H. pusillus (Motschulsky, 1850), H. brevis (Motschulsky, 1844), H. anxius (Duftschmid, 1812), H. politus (Dejean, 1829), Dyschirius rufipes (Dejean, 1825), Ophonus diffinis (Dejean, 1829), Syntomus truncatellus (Linnaeus, 1761), Cicindela gracilis (Pallas, 1775), C. germanica (Linnaeus, 1758), as well as darkling beetles: Pedinus femoralis (Linnaeus, 1767), Opatrum sabulosum (Linnaeus, 1761), Blaps lethifera Marsham, 1802.

Grass thermomesophiles (GTM). These insects displayed maximal abundance in the TR ecosystems grass stands of the forest-steppe and steppe catenas and were represented by the ground beetles: Bembidion lampros (Herbst, 1784), B. femoratum (Sturm, 1825), Poecilus punctulatus (Schaller, 1783), Pterostichus gyrosus (Motschulsky, 1866), P. macer (Marsham, 1802), Amara apricara (Paykull, 1790), A. tibialis (Paykull, 1798), Curtonotus convexiusculus (Marsham, 1802), C. cribricollis (Chaudoir, 1846), Harpalus fuscipalpis (Sturm, 1818), Polystichus connexus (Fourcroy, 1785), Cymindis angularis (Gyllenhal, 1810), C. cylindrica Motschulsky, 1844, Microlestes minutulus (Goeze, 1777), Dyschirius globosus (Herbst, 1784), Calosoma denticolle (Gebler, 1833), as well as some darkling beetles Gonocephalum pusillum (Fabricius, 1792).

Grass thermohygrophiles (GTH). The group was found to have maximal abundance in the waterlogged $\mathrm{AC}$ ecosystems of steppe catenas and was comprised mostly of the ground beetles Bradycellus collaris (Paykull, 1798), Blethisa estsholtzi (Zoubkoff, 1829), Harpalus oblitus (LeConte, 1859), Amara tricuspidata (Dejean, 1831), Bembidion fumigatus (Duftschmid, 1812), B. octomaculatum (Goeze 1777), Calosoma auropunctatum (Herbst, 1784), Poecilus cupreus (Linnaeus, 1758), P. lissoderus (Chaudoir, 1876), Chlaenius spoliatus (Rossi, 1790).

Grass thermoxerophiles (GTX). These insets preferred EL grass stands of the dry steppe subzone of steppe zone and were represented by the ground beetles Carabus bessarabicus (Fischer von Waldheim, 1823), Poecilus crenuliger (Chaudoir, 1876), Amara timida (Motschulsky, 1844), Ophonus puncticollis (Paykull, 1798), Harpalus hirtipes (Panzer, 1796), H. optabilis (Dejean, 1829), H. brevis Motschulsky, 1844, Taphoxenus tilesii (Fischer von Waldheim, 1823), T. gigas (Fischer von Waldheim, 1823), as well as some darkling beetles: Tenthyria nomas (Pallas, 1781), Platyscelis hypolitha (Pallas, 1781), Blaps halophila (Fischer von Waldheim, 1822). 
Grass ardoxerophiles (GAX). They preferred deserted steppes of the EL positions in the deserted steppe subzone of steppe zone and are represented by the ground beetles Harpalus caspius (Steven, 1806), $H$. salinus (Dejean, 1829), H. calathoides (Motschulsky, 1844), Cymindis variolosa (Fabricius, 1794), C. decora (Fischer von Waldheim, 1829), Pseudotaphoxenus rufitarsis (Fischer von Waldheim, 1823), as well as some darkling beetles: Platyscelis picipes (Gebler 1833), Blaps grandulata (Gebler 1825), Anatolica lata (Steven, 1829).

Grass ardohygrophiles (GAH). The beetles from this group were found to prefer saline mires of the AC ecosystems in the deserted steppe subzone and were represented by the ground beetles: Bembidion tenellum (Erichson, 1837), Agonum viridicupreum (Goeze, 1777), Poecilus subcoeruleus (Quensel, 1806), Ophonus steveni (Dejean, 1825), O. rufibarbis (Fabricius, 1792), Microlestes plagiatus (Duftschmid, 1812), Cymindis picta (Pallas, 1771), Brachinus explodens (Duftschmid, 1812), Elaphrus aureus (Muller, 1821), Poecilus cupreus (Linnaeus, 1758), as well as some darkling beetles: Crypticus zuberi (Marseul, 1869), Oodescelis similes (Kaszab, 1938), Belopus procerus (Mulsant, 1854), B. filiformis (Motschulsky, 1872).

\section{Community structure}

The proportion of beetles belonging to different ecological groups was found to be specific for the forest-steppe tree stand faunas. For instance, the ground beetle fauna of the park forest was characterized by almost equal proportions of forest psychroxerophiles and psychromesophiles (42 and 37\%, respectively) with $13 \%$ of the forest cryomesophiles. The ground beetle taxocoenes of the semihydromorphic insular forests of the northern and southern forest-steppe and steppe zones had a different combination of ecological groups, dominated by forest psychromesophiles (48$85 \%$ ). The proportion of forest xeromesophiles was shown to reach $18 \%$ only in the insular tree stands of the northern forest-steppe, being hardly significant (1$2 \%$ ) more southward. Specific ecogroup structures were observed in the assemblages of the hydromorphic insular forests, flooded in spring by melting snow. In those biotopes forest psychrohygrophiles accounted for $51 \%$. Alongside with them, quite significant $(21 \%)$ contribution was made by forest cryohygrophiles.

Thus beetle faunal assemblages in all three types of the forest-steppe tree stands were quite different in their ecological group structure from those in the taiga zone, where the natural forests were shown to be dominated by forest cryomesophiles, while the terrace insular forests were dominated by forest cryo- and psychrophiles in equal proportions. The insular forest tree stands of the West-Siberian Plain were dominated by forest psychroxeromesophiles and psychromesophiles.

The West Siberian forest-steppe tree stands showed much less difference between each other in beetle fauna species composition and abundance, than with faunas of the taiga zone.

Comparison of ecological group assemblages of the taiga and forest-steppe zone by using the Pogozhev's index with a fixed increment from 0 to 1 showed that 3 subsets of the ground beetle taxocoenes could be distinguished: taxocoenes of the a) climax taiga with the index not exceeding 0.2 ; b) forest-steppe insular tree stands with the index of $0.2-0.5$; and c) mired taiga and forest-steppe tree stands with the index of difference between themselves of 0.4 . The index of difference among these 3 subsets in no less than 0.8 , which can be regarded as evidence of their different origin and subsequent genesis (Fig. 1).

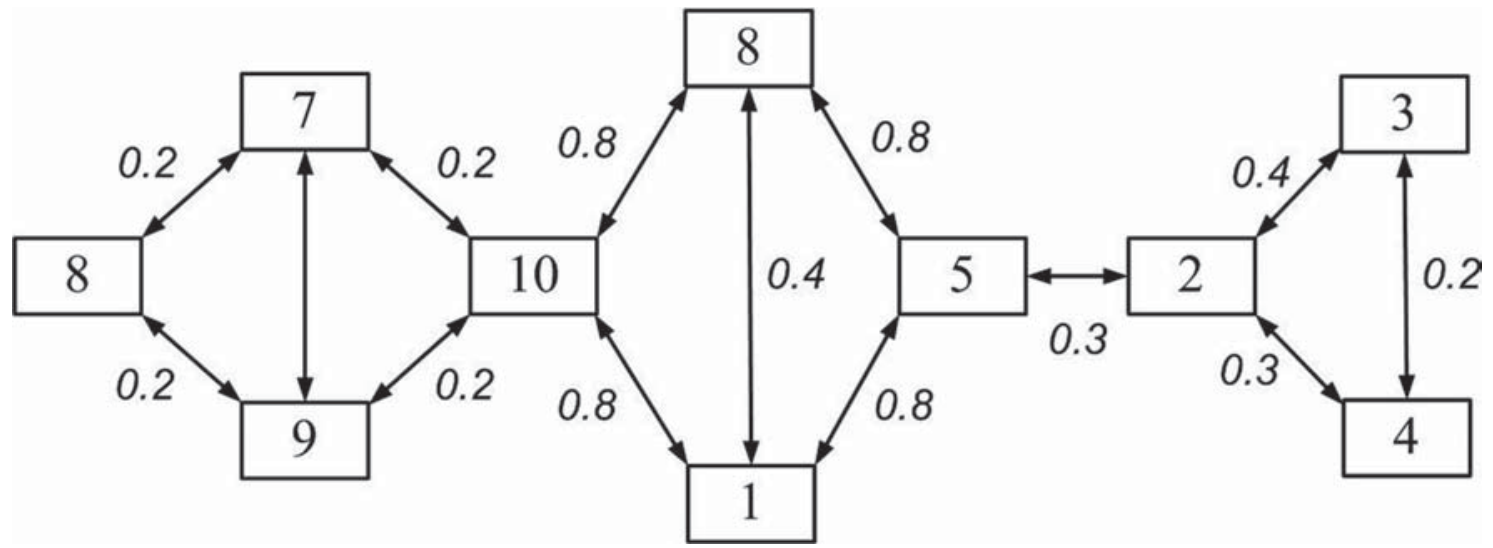

Figure 1. The dissimilarity index of the ground beetles taxocoenes of the tree stands in the forest, forest-steppe and steppe zones of the West Siberian Plain. The habitats: 1 - swamped insular birch forest, 2 - semihydromorphic insular birch forest in the northern foreststeppe, 3 - semihydromorphic insular birch forest in the southern forest-steppe, 4 - semihydromorphic insular birch forest in the dry steppe, 5 - park birch forest in the forest-steppe, 6 - West-Siberian northern taiga, 7 - West-Siberian middle taiga, 8 - West-Siberian swamped middle taiga, 9 - West-Siberian southern taiga, and 10 - West-Siberian riverside southern taiga.

Рисунок 1. Индекс различия таксоценов жужелиц древостоев лесной, лесостепной и степной зон Западно-Сибирской равнины. Таксоцены из: 1 - заболоченного березового колка, 2 - полугидроморфного березового колка в северной лесостепи, 3 полугидроморфного березового колка в южной лесостепи, 4 - полугидроморфного березового колка в зоне сухой степи, 5 паркового березняка в лесостепи, 6 - западносибирской северной тайги, 7 - западносибирской средней тайги, 8 - западносибирской заболоченной средней тайги, 9 - западносибирской южной тайги, и 10 - западносибирской приречной южной тайги. 
In the forest-steppe psychrophiles were found to dominate the ground and darkling beetle assemblages of the mesophytic and stepped meadows, as well as tree stands, both in species composition and abundance (not less than 80\%). Cryohygrophiles could be found only in the mires and wet meadows, and even there they contributed not more than $30 \%$ into the ecological group structure. Thermomesophiles accounted for less than $5 \%$ in the mesophytic meadows, whereas thermoxerophiles accounted for not more than $30 \%$ in the meadow steppes.

The ground and darkling beetle assemblages of the grass habitats in the forest-steppe of the West Siberia were shown to be composed of species and individuals from several ecological groups, represented in different proportions. Some habitats had a pronounced dominance of beetles from one ecological group, while the others had marginal ecological structure. The ground beetle taxocoene specific for the forest-steppe zone, was found to assemble in the waterlogged, but drying by mid-summer wet meadows, where as many as 60 $80 \%$ of the animals represented grass psychrohygrophiles, and only $12-15 \%$ and $13 \%$ belonged to forest psychrohygrophiles and grass cryohygrophiles, respectively.

Nonetheless, original ground beetle taxocoene was found in the mesophytic and watershed moderately wet meadow of the TR positions on catena: the taxocoene was dominated by grass psychromesophiles (57-67\%) with a certain contribution by forest psychromesophiles (10-32\%). The darkling beetles of the assemblage were dominated by the grass psychromesophiles (94-100\%). The contribution of psychrobalancephiles in the meadow assemblages was practically negligible both for the ground $(4 \%)$ and darkling $(6 \%)$ beetles. Thermoxerophiles were not observed in such communities even in the very dry years.

The meadow steppes and dry meadows at the summits of steppe ridges, i.e. the habitats experiencing periodic moderate water deficit, theoretically can be expected to be inhabited by some xerophilous organisms. However, the latter were found among neither the ground, nor the darkling beetles; instead, grass psychrobalancephiles $(62-76 \%)$ in combination with grass psychromesophiles (14-17\%) dominated in such assemblages. Grass thermomesophiles, rather than thermoxerophiles, comprised up to $20 \%$ of the ground beetle faunal assemblages. In contrast, the grass thermomesophilic darkling beetles were not observed in the meadow steppes. All three meadow faunal assemblages were characterized by the highest abundance in the forest-steppe. Thus it makes sense to regard them as a single meadow type, indigenous in the forest-steppe, the latter essentially being the park-meadow zone.

Alongside with indigenous insect faunal assemblages, dominated either by psychrohygrophiles, or psychromesophiles, or grass psychrobalancephiles, some forest-steppe habitats were shown to have assemblages with an obscure dominant structure of ecological groups, changing according to hydrothermal or hydrochemical fluctuations in the environment.

For example, the ground beetle assemblages of the wet meadows were almost equally dominated by grass and forest psychromesophiles (31 and 26\%, respectively) and grass psychrohygrophiles. The ground beetle assemblages of the mesohalophytic meadow on solonetz had grass psychromesophiles and thermomesophiles contributing nearly the same proportions (42 and $48 \%$, resp.), most likely because of the specific properties of the solonetz horizon in the middle of the profile and very good thermoconductivity of the upper solonetz horizon. At the same time $98 \%$ the darkling beetle assemblages of the halomesophytic solonetz meadow belonged to the psychromesophiles, rather than thermomesophiles or thermoxerophiles. The middle solonetz displayed similarly non-impressive ecological group structure with about equal representation of psychromesophiles (33\%) and grass psychrobalancephiles (28\%). The darkling beetle taxocoene in its ecological group structure showed the dominance of psychrobalancephiles $(81 \%)$, with the rest contributed by psychromesophiles both in ground and darkling beetle assemblages. All these varying assemblages should be considered as proto-communities with marginal, or transitional between indigenous communities, features and very unstable in time ecological structure. This phenomenon is very characteristic for the forest-steppe biome.

Notably, the chernozemic steppe subzone of the Central Kazakhstan in the EL-positions displayed the ground beetle ecogroups assemblages that were very similar to the ones in the meadow steppes and stepped meadows of the forest-steppe zone. Both study sites were dominated by grass psychrobalancephiles (62 and $54 \%$, resp.), while thermoxerophiles contributed just $24 \%$ into the ground beetle assemblages only in the south of the subzone, where chernozems are represented by their southern subtype, very similar to the dark kastanozems. The ground beetle taxocoenes of the chernozemic steppes were shown to have only $6 \%$ of the thermoxerophiles, $10 \%$ of the thermomesophiles, and similarly to the meadow steppes of the forest-steppe zone being dominated by psychrobalancephiles $(81 \%)$. The TR positions of chernozemic steppes catenas had the ground beetle taxocoenes dominated by thermomesophiles $(75 \%)$ and the darkling beetle taxocoenes dominated by psychromesophiles (57\%). The thermoxerophiles accounted only for $2 \%$ in the ground beetle assemblages and $17 \%$ in the darkling beetle ones. Hence both taxocoenes seemed to be more of a meadow, rather than steppe, character.

Undoubtedly steppe character could be attributed to the ground and darkling beetle assemblages on the EL positions in the dry steppe on kastanozems as they showed a very pronounced dominance of thermoxerophiles (94\% among the ground beetles and 85\% among the darkling ones). The TR positions in the dry steppe zone were dominated by thermomesophiles ( $84 \%$ among the ground beetles and $67 \%$ among the darkling ones). 


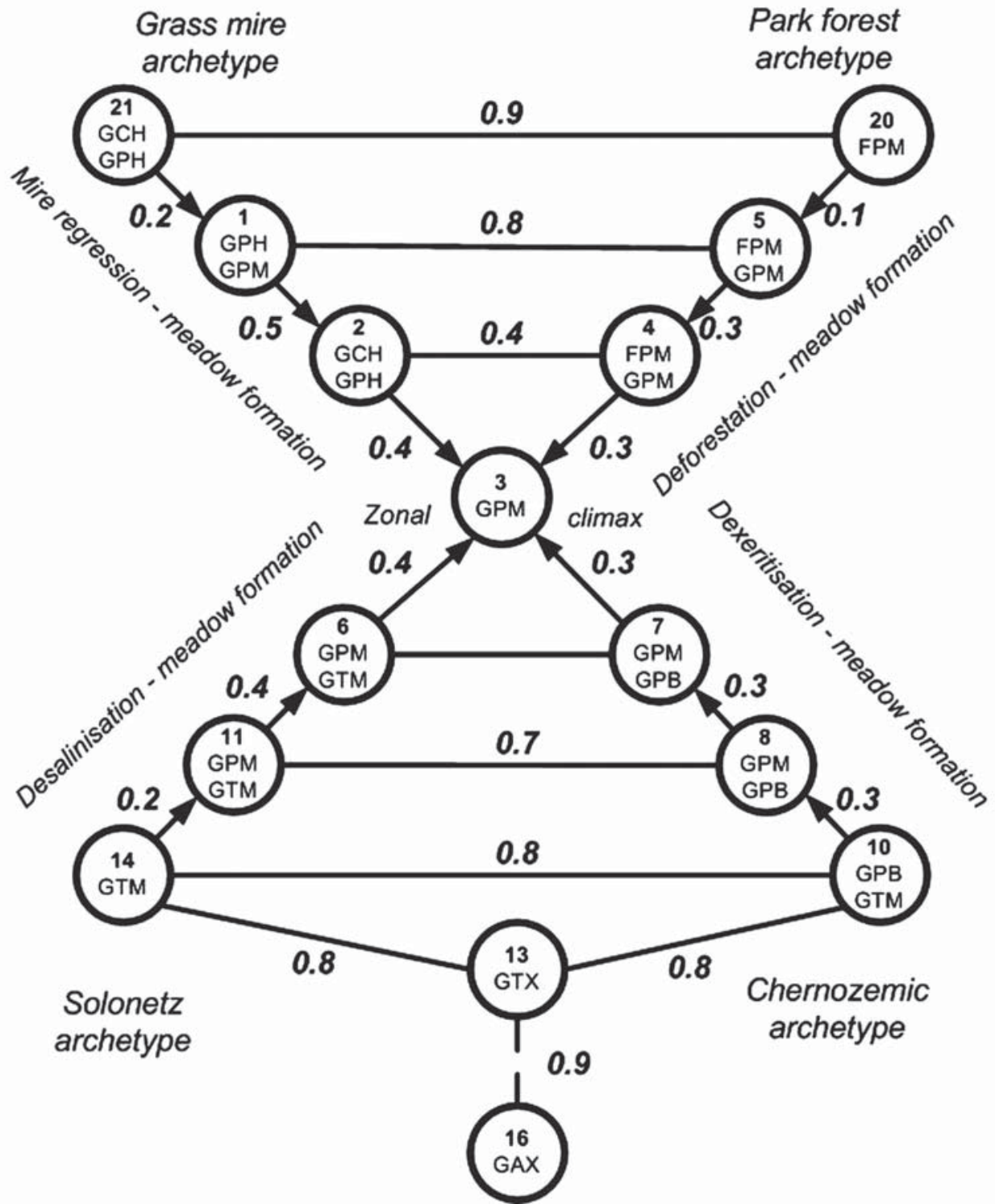

Figure 2. The diagram of ecological linkage and successional transformations of grass ground beetle communities in the West Siberian and Central Kazakhstan forest-steppe. $\mathrm{M}_{\mathrm{p}}-0.1=5 \mathrm{~mm}$.

Рисунок 2. Схема экологических связей и сукцессионных трансформаций травяных сообществ жуков-жужелиц в ЗападноСибирской лесостепи Центральном Казахстане. $\mathrm{M}_{\mathrm{p}}-0,1=5$ мм.

The deserted steppe assemblages were dominated by the ardoxerophiles thermoxerophiles (94-96\%).

The comparison of the ecological structure of the studied taxocoenes by using the dissimilarity index (p) allowed distinguishing several subsets of communities in the ground and darkling beetle assemblages. The dissimilarity index within the subsets is rather low $(0.2-$ 0.4 ), while between the subsets exceeds 0.5 and can even reach its maximum of 1 (Fig. 2).

The first subset combining the taxocoenes of the ground and darkling beetles of the park forest (one of the indigenous biogeocoenotic archetypes of the forest-steppe biome), as well as of the near-to-forest-
(No.5), watershed (No.4) and mesophytic (No.3) meadows is considered to reflect ecogenetic succession of the gradual changing of forest derivatives into a typically meadow coenosis. This process is marked by the substitution of forest psychromesophiles with grass psychromesophiles in the ecological assemblages. In the course of succession the share of forest psychromesophiles in species composition decreases from 70 to $10 \%$, while the share of grass psychromesophiles increases from 15 up to $67 \%$.

The second subset joins together the taxocoenes of the ground and darkling beetles of the semihydromorphic habitats, thus reflecting succession changes of the 
gradual degradation of grass mires (that represent another biogeocoenotic archetype of the forest-steppe biome) into the wet (No.1), moist (No.2) and then mesophytic (No.3) meadows, according to the historical process of the West-Siberian forest-steppe drying during the second half of Holocene. The beetle fauna responded by the gradual dropping out of grass cryo-, and then psychrohygrophiles from $64 \%$ to $2 \%$, and their total substitution by grass psychromesophiles.

The third subset is comprised of the taxocoenes of the ground and darkling beetles of the meadow (No.8) and dry (No.10) steppes on chernozems, as well as of the dry meadow on the middle solonetz (No.7) and once again of the mesophytic meadow on the meadowchernozemic soil (No.3). This subset illustrates well the ecogenetic succession of the gradual changing of the dry meadows (yet another biogeocoenotic archetype of the forest-steppe biome) into true meadows, according to the historical trend of extra water discharge through the superficial water flow into the Aral, the drainage of the territory and partial erosion of hills in mid-Holocene [The structure..., 1974]. As a result, the balance between organic matter mineralization-humification shifted towards humus accumulation, which led the metamorphosis of soil and biogeocoenoses towards meadow development. Under such successional scenario psychrobalancephiles are substituted by the grass psychromesophiles. The proportion of psychrobalancephiles in the assemblages gradually diminished from 67 to 33 and further to $17 \%$, while the grass psychromesophiles proportion increases from 4 to 28 and eventually up to $54-57 \%$. The representatives of the thermoxerophilous ecogroup do not participate in the process, instead of themselves allowing thermomesophiles to contribute up to $25 \%$. However, psychrobalancephiles and psychromesophiles continue to be important ecogroups of the beetle fauna.

The fourth subset combines the taxocoenes of the ground and darkling beetles of the meadow solonetz of the forest-steppe and steppe zones (Nos.14, 11, 6) and once again of the mesophytic meadows (No.3). This subset reflects the ecogenetic succession of the gradual changing of the archetypical halocoenoses into glycocoenoses. In this subset the thermomesohalophiles are gradually substituted by grass psychromesophiles. The share of the former decreases from 84 to $13 \%$, the share of the latter increasing commensurately.

\section{Discussion}

The study presented above allows drawing several conclusions worth discussing.

1. Successions in the forest-steppe zone have many scenarios according to different ecological trends, common for the forest-steppe landscape.

2. All four scenarios described here originate in their own coenotic archetypes, resembling each other neither in form, nor in biotic composition and structure. All those grass mires, park forests, halocoenoses and dry meadows were inherited by the forest-steppe from the preceding it in the Quaternary history Periglacial period with of extreme heterogeneity of habitats and biodiversity.

3. Despite the difference between archetypes, their phylocoenogenesis went in one and the same direction, i.e. towards meadow coenoses dominated by plantsmesophytes and grass psychromesophylous insects. Meadows seem to be the ecosystems of the biogeocoenotic climax in the forest-steppe, although in catenas they occupy not only eluvial, but transitional positions, where environmental conditions represent very well the hydrothermal standards for the forest-steppe zone, and where the biological turnover is balanced best [The structure, functioning and evolution..., 1976].

4. If meadows and their corresponding zoocoenoses represent climax ecosystems universal for all scenarios of successional sequences and phylocoenogenesis, and if they can be found in a wide range of habitats and account for not less than $70 \%$ of the zone area [Vagina, 1962], then what are the reasons to consider fragmentary insular forests and meadow steppes, unimpressive in composition and structure, and which V.V. Alekhin [1934] called a "vegetation anomaly", to be zonal reference ecosystems?

5. We suggest to denounce the landscape-zonal stereotype, of which many are already tired, and consider the forest-steppe zone and its corresponding biome to be indigenous phenomenon, rather than the marginal mix. A meadow coenosis in such a case gets a status of the zonal reference ecosystem of the considered zone, rather than being a secondary state intrazonal intrusion. It is turn the considered zone should be referred to as a meadow zone, rather than the one of steppes and forests.

6. The analysis of the ecological group dominance in beetle faunas provided reasons to consider meadow and dry steppe communities on chernozems as belonging to the meadow zone, rather than the steppe one, as their leading positions are occupied by psychrobalancephiles and mesophiles and not xerophiles. Accordingly, the chernozemic steppe subzone much more naturally can be joined with the meadow zone, rather than the steppe one. The former is dominated by chernozems and humification processes, while the latter is dominated by kastanozems and organic matter mineralization processes. In the meadow zone zoocoenoses are based on psychrobalancephiles and mesophiles, while in the steppe zone thermoxerophiles are the major component of its zoocoenoses.

7. We believe that the concept of broad expansion of forest and steppe species into the forest-steppe and their balanced co-existence there, at least in case of ground beetles, darkling beetles and some other groups of animals, is a myth. Entomological assemblages of the forest-steppe tree and grass stands are quite indigenous and dissimilar to the ones of both Siberian taiga and steppe, at the same displaying certain similarity (30-40\%) with the forest-steppe faunal assemblages of the southern Urals and the Russian Plain [Mordkovich 
et al., 2010]. Occurrence of some individuals of southern insects in the north of the steppe zone should be regarded as a manifestation of a trait common to all biota, i.e. expansion [Mordkovich, 2005], or stochastic attempts to expand one's geographical area, rather than a vector response to the global warming and formation of sustainable arid communities.

8. In contrast to the stenopotent cryo- and thermophiles, forest-steppe psychrophiles with their euripotency under certain conditions are capable of broad geographic expansion and even colonization of new habitats in the forest and steppe zones, which are at the initial and middle stages of succession after fires, floodings, landslides, permafrost ground shifts, forest clearance, ploughing and other stresses. The share of psychrophiles in such communities may reach $70-80 \%$.

9. In view of all the data presented, the latitudal zonality in Eurasia appears to be quite a complex system, rather than a sequential gradient of environmental conditions. It is headed by the forest-steppe biome (=boreal savanna), that arranges the whole range of other temperate biomes into a single ecosystem of the higher complexity rank. In case of the future climate changes ecological collisions in the forest-steppe may turn out to be the major driving force of biodiversity transformation in the West Siberian region.

\section{Acknowledgements}

The study was financially supported by the Russian Foundation for Basic Research (grants \#\# 95-0412461a, 01-04-49533a. The author thanks Dr. I.I. Lyubechanski for the possibility to use his published data on ground beetles. The author is thankful to Dr. R.Yu. Dudko for checking the taxonomical attribution of the ground beetles and to Dr. N.B. Naumova for translating the paper.

\section{References}

Alekhin V.V. 1934. [Central chernozemic steppes]. Voronezh. 273 pp. [in Russian]

Arnoldi K.V. 1965. [The forest-steppe of the Russian Plain and the attempts of its zoogeographic and coenotic characteristics based o insects] // Trudy Tsentral'no-Chernozyomnogo gos. zapovednika. Voronezh. Vol.8. P.138-166 [in Russian].

Berseneva I.A. 2006. [Climates of the arid zone of Asia]. Moscow: Nauka Publ. 271 pp. [in Russian].

Ghilarov M.S. 1965. [Zoological method of soil diagnostics]. Moscow: Nauka Publ. 273 pp. [in Russian].

Khansky I. 2010. [A shrinkling world. Ecological consequences of habitat extinction]. Translated from English. Moscow: KMK Publ. 340 pp. [in Russian].

Magurran E. 1992. [Ecological diversity and its measurement]. Translated from English. Moscow: Mir Publ. 1992. 181 pp. [in Russian].

Mordkovich V.G. 2005. [The basics of biogeography]. Moscow: KMK-Press. 236 pp. [in Russian, with English summary].

Mordkovich V.G. 2010. [Are there many typical forest species of ground beetle in the tree stands of the West-Siberian foreststeppe?] // Evraziatskiy Entomologicheskiy Zhurn. Vol.9. No.4. P.607-613 [in Russian, with English summary].

Mordkovich V.G. 2011. [Ecological groups of darkling beetles species (Coleoptera, Tenebrionidae) in West Siberia and Central Kazakhstan plains] // Evraziatskiy Entomologicheskiy Zhurn. Vol.10. No.4. P.409-414 [in Russian, with English summary].

Mordkovich V.G., Barkalov A.V., Vasilenko S.V., Grishina L.G., Dubatolov V.V., Dudko R.Yu., Zinchenko V.K., Zolotarenko G.S., Legalov A.A., Marchenko I.I., Chernyshev C.E. 2002. [Species richness of the arthropods of the West Siberia Plain] // Evraziatskiy Entomologicheskiy Zhurn. Vol.1. No.1. P.3-20 [in Russian, with English summary].

Mordkovich V.G., Lyubechanskii I.I. 2010. [Ecological groups of the ground beetles (Coleoptera, Carabidae): the nature, principles of grouping, compositions and usability] // Evraziatkiy Entomologicheskiy Zhurn. Vol.9. No.2. P.195-202 [in Russian, with English summary].

[The structure, functioning and evolution of the Baraba biogeocoenoses]. 1974. Novosibirsk: Nauka Publ. Vol.1. 307 pp. [in Russian].

[The structure, functioning and evolution of the Baraba biogeocoenoses]. 1976. Novosibirsk: Nauka Publ. Vol.2. 495 pp. [in Russian].

Vagina T.A. 1962. [The Baraba meadows]. Novosibirsk: Nauka Publ. 127 pp. [in Russian]. 